\title{
FREEZE-DRYING KINETICS APPROACH OF SOLUBLE COFFEE. MASS TRANSFER PARAMETERS ESTIMATION
}

\author{
ADINA GHIRIŞAN ${ }^{\mathrm{a}}$, SIMION DRĂGAN ${ }^{\mathrm{a}^{*}}$, VASILE MICLĂUŞ ${ }^{\mathrm{a}}$
}

\begin{abstract}
The present paper presents the freeze-drying kinetics of soluble coffee in order to determine the mass transfer parameters. Several semi-theoretical and empirical models were used to find the best fit to the experimental data. The applied models were compared using the coefficient of determination $\left(R^{2}\right)$, the mean relative percent error $(P)$, the root mean square error (RMSE) and the reduced chi-square $\left(\chi^{2}\right)$. The Midilli model was found to fit better to the experimental freeze-drying data comparative to other models. The Fick's second law was employed to determine the effective diffusion coefficient ( $\left.D_{\text {eff }}\right)$.
\end{abstract}

Keywords: coffee, freeze-drying, moisture ration, drying rate, Fick's diffusion model, effective diffusion coefficient.

\section{INTRODUCTION}

Freeze-drying or lyophilisation is the drying process used to remove the solvent (usually water) from frozen materials. Due to the absence of liquid water and the low temperatures required for the process, more of deterioration and biological reactions are stopped, the quality of materials is preserved, its shelf-life is increased, the loss of flavor and aroma is reduced, and active ingredients can be recovered [1].

The benefits of freeze-drying include also: retention of morphological, biochemical, and immunological properties, high recovery of volatiles, retention of structure, surface area, high yield, and reduced weight for storage, shipping and handling [2].

\footnotetext{
a Universitatea Babeş-Bolyai, Facultatea de Chimie şi Inginerie Chimică, Str. Kogălniceanu, Nr. 1, RO-400084 Cluj-Napoca, Romania

* Corresponding author: sdragan@chem.ubbcluj.ro
} 
Freeze-drying was initially used for the preservation of heat-sensitive bioactive molecules (DNA, enzymes and proteins), pharmaceutical products (antibiotics) and other delicate, solvent impregnated materials [3]. Nowadays, the freeze-drying is used from relatively simple preservable food like coffee, tea, crispy fruits and vegetables, aromatic herbs, to complex biotechnological or pharmaceutical products like microorganisms, cosmetics, enzymes, fine chemicals and ceramic powders [4, 5].

By freeze-drying, the solid, semi-liquid or liquid sample is frozen to a low temperature (about $-40^{\circ} \mathrm{C}$ ) to form a thin layer and then subjected to vacuum when the ice (frozen solvent) is removed by sublimation, during the primary drying stage of the process. As the ice sublimes, the sublimation interface, which started at the outside surface, recedes, and a porous shell of dried material remains. The vaporized solvent (water) is transported through the porous layer of dried material. In contrast with mass transfer, which always flows through the dry layer, heat transfer can take place by conduction through the dry layer or through the frozen layer [6-8].

Several mathematical equations describing mass and energy transfer have been developed for modeling the freeze-drying process [9-11]. Such models account for the removal of frozen water only (sublimation model) or the removal of frozen and bound water (sorption sublimation model), examine the methods of supplying heat and the diffusion mechanisms, describe steady or unsteady state processes, or analyze both transfers under various processing conditions. Pseudo-steady state exists as long as the amount of heat entering into the product is balanced by the amount of heat removed through sublimation of ice. Under these conditions the product temperature does not change significantly.

The use of the rigorous unsteady state mathematical model of Sadikoglu and Liapis has been found to describe satisfactorily the experimental dynamic behavior of the primary and secondary drying stages of bulk solution freeze drying of pharmaceuticals in trays [10].

The diffusion of water vapor in the partially dried layer is one of the major factors affecting the mass transfer rate. The diffusivity is closely related to the pore size. Large ice crystals will be helpful for the movement of water. The pressure difference is essentially the driving force for the transport of water vapor. The smallest chamber pressure gives the highest ice sublimation rate [11].

In the present work, semi-theoretical and empirical mass transfer models used for the drying of the thin-layer samples were fitted to experimental data obtained in a laboratory freeze-dryer in order to investigate the applicability of these models to the soluble coffee freeze-drying kinetics [13, 16]. 


\section{RESULTS AND DISCUSSION}

\section{Interpretation of freeze-drying behavior}

The evolution of soluble coffee freeze-drying characterized by the drying curve is shown in Figure 1. The sample moisture content $M$ was calculated on a dry basis as in other works was made [12-14]. Drying of the frozen coffee solution started with the initial moisture content of $8.54 \mathrm{~kg}$ water $/ \mathrm{kg}$ dried matter) and decreases until 0.12 ( $\mathrm{kg}$ water $/ \mathrm{kg}$ dried matter) in 360 minutes. The water loss was measured at intervals of 30 minutes.

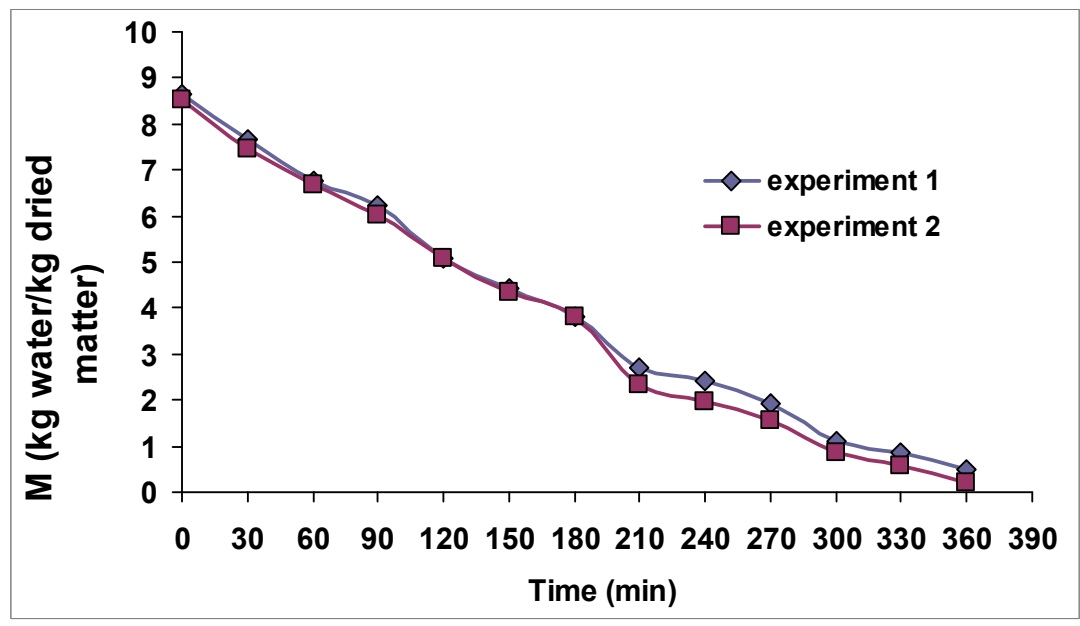

Figure 1. Drying curves

As the drying curves show, the results can be considered reproducible, as long as the drying parameters are constant. Some differences between moisture content appear in the second period, after 210 minutes from the beginning of the drying process.

In order to analyze the freeze-drying kinetics, the moisture content is forwards expressed as moisture ratio (MR), calculated by equation (1) or by the simplified form (2) applied when the equilibrium moisture contents $M_{e}$ is enough low [15]:

$$
\mathrm{MR}=\frac{\mathrm{M}-\mathrm{M}_{\mathrm{e}}}{\mathrm{M}_{0}-\mathrm{M}_{\mathrm{e}}}=\mathrm{e}^{-\mathrm{kt}}
$$




$$
\mathrm{MR}=\frac{\mathrm{M}}{\mathrm{M}_{0}}=\mathrm{e}^{-\mathrm{kt}}
$$

where: $\mathrm{k}$ is the drying constant $\left(\mathrm{min}^{-1}\right), \mathrm{M}, \mathrm{M}_{0}$ and $\mathrm{M}_{\mathrm{e}}$ - moisture content at each measured time, at the beginning and at the final/equilibrium ( $\mathrm{kg}$ moisture/kg dried matter), $t$ - the drying time (min).

The change of the moisture ratio (MR) during freeze-drying is presented in Figure 2.

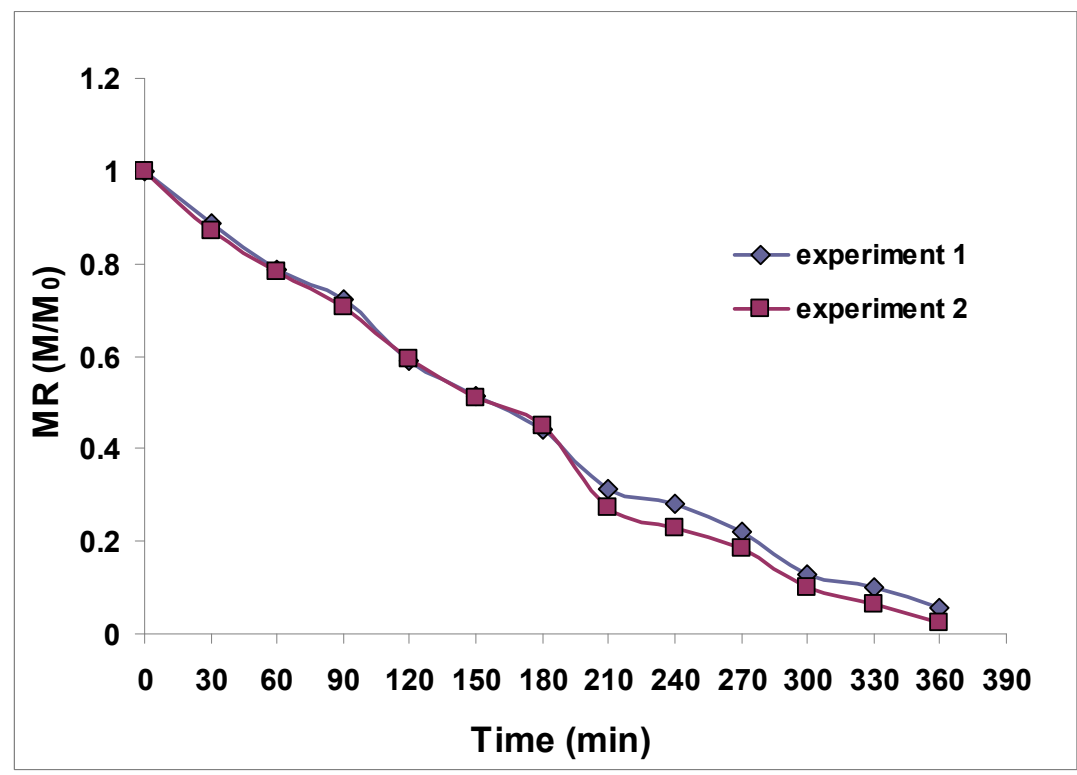

Figure 2. Moisture ration (MR) versus freeze-drying time.

The average values of moisture ratio MR obtained at each experimental time were fitted to 10 semi-theoretical or empirical drying models, usually used for convective and/or freeze-drying of thin-layer samples. The used models and the obtained drying constants, determined by Matlab Curve Fitting Programme, are shown in Table 1.

In order to compare the best fit for each mathematical model the next statistical parameters are used: the coefficient of determination $\left(R^{2}\right)$, the mean relative percent error $(P)$, the root mean square error (RMSE) and the reduced chi-square $\left(\chi^{2}\right)$. The higher values of $R^{2}$ and the lower values of $\mathrm{P}, \mathrm{RMSE}$ and $\chi^{2}$ will give the goodness of the fit. These parameters are calculated by equations (3) - (6), and are shown in Table 2 . 
FREEZE-DRYING KINETICS APPROACH OF SOLUBLE COFFEE...

Table 1. Models used for freeze-drying of soluble coffee $[13,16]$

\begin{tabular}{|c|c|c|}
\hline Nr. Crt. & Model name and equation & Drying constants \\
\hline 1 & $\begin{array}{l}\text { Newton } \\
M R=\mathrm{e}^{-\mathrm{kt}}\end{array}$ & $\mathrm{k}=0.005457$ \\
\hline 2 & $\begin{array}{l}\text { Page } \\
\mathrm{MR}=\mathrm{e}^{-\mathrm{kt}^{\mathrm{m}}}\end{array}$ & $\begin{array}{l}\mathrm{k}=0.0005428 \\
\mathrm{~m}=1.44\end{array}$ \\
\hline 3 & $\begin{array}{l}\text { Henderson \& Pabis } \\
\mathrm{MR}=\mathrm{a} \cdot \mathrm{e}^{-\mathrm{kt}}\end{array}$ & $\begin{array}{l}\mathrm{k}=0.005876 \\
\mathrm{a}=1.072\end{array}$ \\
\hline 4 & $\begin{array}{l}\text { Logarithmic } \\
\mathrm{MR}=\mathrm{a} \cdot \mathrm{e}^{-\mathrm{kt}}+\mathrm{c}\end{array}$ & $\begin{array}{l}k=0.002862 \\
a=1.534 c=-0.5142\end{array}$ \\
\hline 5 & $\begin{array}{l}\text { Two term } \\
M R=a \cdot e^{-k_{0} t}+b e^{-k_{1} t}\end{array}$ & $\begin{array}{l}k_{0}=0.005502 k_{1}=0.00553 \\
a=0.3493 \quad b=0.661\end{array}$ \\
\hline 6 & $\begin{array}{l}\text { Two term exponential } \\
M R=\mathrm{ae}^{-\mathrm{kt}}+(1-\mathrm{a}) \mathrm{e}^{-\mathrm{kat}}\end{array}$ & $\begin{array}{l}\mathrm{k}=0.005457 \\
\mathrm{a}=0.9976\end{array}$ \\
\hline 7 & $\begin{array}{l}\text { Wang and Singh } \\
M R=1+a t+b t^{2}\end{array}$ & $\begin{array}{l}a=-0.0040 \\
b=3.75 \cdot 10^{-6}\end{array}$ \\
\hline 8 & $\begin{array}{l}\text { Approximation of diffusion } \\
\mathrm{MR}=\mathrm{ae}^{-\mathrm{kt}}+(1-\mathrm{a}) \mathrm{e}^{-\mathrm{kbt}}\end{array}$ & $\begin{array}{l}k=0.01112 \\
a=-32.25 b=0.9737\end{array}$ \\
\hline 9 & $\begin{array}{l}\text { Modified Henderson \& Pabis } \\
\mathrm{MR}=\mathrm{ae}^{-\mathrm{kt}}+\mathrm{be}^{-\mathrm{gt}}+\mathrm{ce}^{-\mathrm{ht}}\end{array}$ & $\begin{array}{l}a=-0.1947 \quad b=1.153 \quad c=0.0414 \\
k=0.816 g=0.006346 h=0.87\end{array}$ \\
\hline 10 & $\begin{array}{l}\text { Midilli et al. } \\
\mathrm{MR}=\mathrm{ae}^{-\mathrm{kt}^{\mathrm{m}}}+\mathrm{bt}\end{array}$ & $\begin{array}{l}k=0.0003916 \\
a=0.9702 b=-5.17 \cdot 10^{-5} m=1.488\end{array}$ \\
\hline
\end{tabular}

$$
\begin{aligned}
\mathrm{P} & =\frac{100}{\mathrm{~N}} \sum_{\mathrm{i}=1}^{\mathrm{N}} \frac{\left|\mathrm{MR}_{\text {expi }}-\mathrm{MR}_{\text {prei }}\right|}{\mathrm{MR}_{\text {expi }}} \\
\mathrm{RMSE} & =\left[\frac{1}{\mathrm{~N}} \sum_{\mathrm{i}=1}^{\mathrm{N}}\left(\mathrm{MR}_{\text {expi }}-\mathrm{MR}_{\text {prei }}\right)^{2}\right]^{1 / 2} \\
\chi^{2} & =\frac{\sum_{\mathrm{i}=1}^{\mathrm{N}}\left(\left(\mathrm{MR}_{\text {expi }}-\mathrm{MR}_{\text {prei }}\right)^{2}\right.}{\mathrm{N}-\mathrm{n}}
\end{aligned}
$$




$$
\mathrm{R}^{2}=1-\frac{\sum_{\mathrm{i}=1}^{\mathrm{N}}\left(\mathrm{MR}_{\text {expi }}-\mathrm{MR}_{\text {prei }}\right)^{2}}{\sum_{\mathrm{i}=1}^{\mathrm{N}}\left(\mathrm{MR}_{\text {prei }}\right)^{2}}
$$

where $M R_{\text {expi }}$ are the experimental values of moisture ratios, $M R_{\text {prei }}$ are the predicted moisture ratios, $\mathrm{N}$ are the number of observations, and $\mathrm{n}$ is the number of constants.

Table 2. Values of statistical parameters

\begin{tabular}{|c|c|c|c|c|}
\hline Model & $\mathbf{R}^{2}$ & RMSE & $\chi^{\mathbf{2}}$ & $\mathbf{P}$ \\
\hline Newton & 0.9426 & 0.0058 & $3.4039^{*} 10^{-5}$ & 0.4275 \\
\hline Page & 0.9771 & 0.0189 & $3.5833^{*} 10^{-4}$ & 0.0403 \\
\hline Henderson \& Pabis & 0.9508 & 0.0299 & $8.9187^{*} 10^{-4}$ & 0.1231 \\
\hline Logarithmic & 0.9741 & $4.3325 \mathrm{e}^{-04}$ & $1.8771^{*} 10^{-7}$ & 0.0656 \\
\hline Two term & 0.9448 & 0.0011 & $1.1899^{*} 10^{-6}$ & 0.3846 \\
\hline Two term exponential & 0.9426 & 0.0058 & $3.3970^{*} 10^{-5}$ & 0.4275 \\
\hline Wang \& Singh & 0.9755 & 0.0110 & $1.2105^{*} 10^{-4}$ & 0.1391 \\
\hline $\begin{array}{c}\text { Approximation of } \\
\text { diffusion }\end{array}$ & 0.9757 & 0.0189 & $3.5752^{*} 10^{-4}$ & 0.0013 \\
\hline $\begin{array}{c}\text { Modified Henderson \& } \\
\text { Pabis }\end{array}$ & 0.9595 & 0.0231 & $5.3364^{*} 10^{-4}$ & 0.1022 \\
\hline \begin{tabular}{c} 
Midilli et al. \\
\hline
\end{tabular} & 0.9785 & 0.0023 & $5.4395^{*} 10^{-6}$ & 0.0480 \\
\hline
\end{tabular}

As the statistical results show, the highest value of $\mathrm{R}^{2}$ and the lowest value of $P, R M S E$ and $\chi^{2}$ were obtained from the Midilli et al. model, $R^{2}=0.9785$, $\mathrm{P}=0.0480$, RMSE $=0.0023$ and $\chi^{2}=5.4395^{\star} 10^{-6}$. Comparative results are obtained by logarithmic, Wang \& Singh, and approximation of diffusion models. 
The choise of these models as good models for the behavior of soluble coffee freeze-drying is confirmed by the plot of the predicted and experimental moisture ratio values, which is a straight line banding around $45^{\circ}$, as Figure 3 indicates.

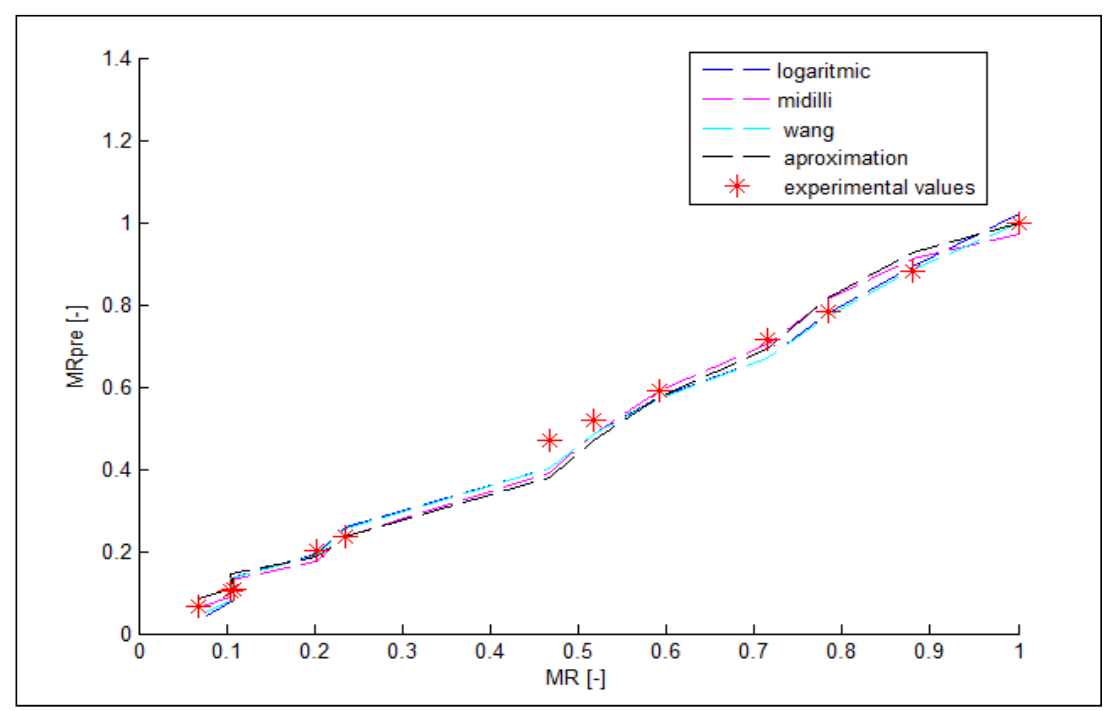

Figure 3. Comparison of experimental and predicted moisture ratio by established models

\section{Determination of drying rate}

The freeze-drying rate is expressed by equation (7) describing the amount of water loss on surface area and time.

$$
\mathrm{DR}=\frac{\Delta \mathrm{M}}{\mathrm{A} \cdot \Delta \mathrm{t}}
$$

where $A=0.0017 \mathrm{~m}^{2}$ is the surface area of the tray.

The change of the drying rate with the ratio moisture is shown in Figure 4. As it is shown, the drying process takes place in the falling rate drying period, corresponding to porous materials with low specific surface [17].

The drying rate decreases between $0.32 \mathrm{~kg} / \mathrm{kgm}^{2} \mathrm{~s}$ at $0.025 \mathrm{~kg} / \mathrm{kgm}^{2} \mathrm{~s}$, with the decrease of the moisture content from 8.54 ( $\mathrm{kg}$ water $/ \mathrm{kg}$ dried matter) to 0.12 ( $\mathrm{kg}$ water $/ \mathrm{kg}$ dried matter). 


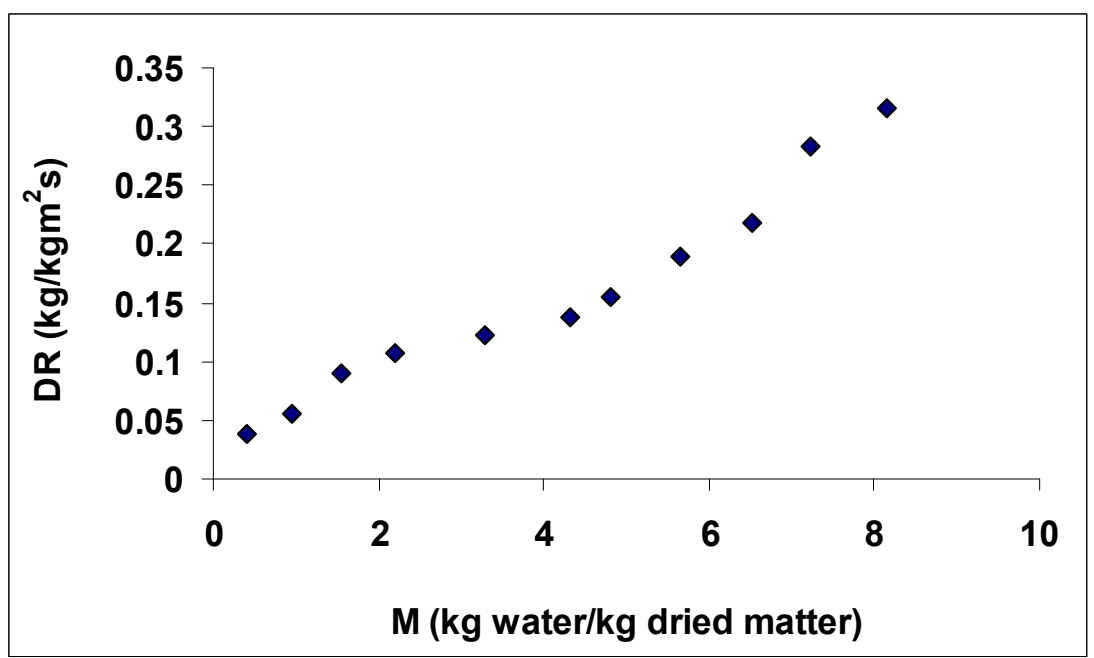

Figure 4. Drying rate versus moisture

\section{Determination of effective diffusivity}

As it was shown in the previous paper [14], the diffusion model developed for mass transfer based on Fick's second law of diffusion, more accurate than heat transfer model, was used in order to determine the diffusion coefficient during freeze-drying:

$$
\mathrm{MR}=\frac{\mathrm{M}}{\mathrm{M}_{0}}=\mathrm{Ae}^{-\mathrm{kt}}=\mathrm{Ae}^{-\frac{\pi^{2} \mathrm{D}_{\text {eff }}}{4 \mathrm{~L}^{2}} \mathrm{t}}
$$

where, $\mathrm{k}$ is known as drying constant, an important parameter in understanding the drying behavior of the material, $L$ - the thickness of the sample, and $D_{\text {eff }}$ the effective diffusion coefficient [12, 14].

In order to determine the effective diffusion coefficients $\left(D_{\text {eff }}\right)$ the experimental drying data in term of $\ln (\mathrm{MR})$ are plotted versus time (Figure 5). The obtained straight line has the slope given as equation (9) shows:

$$
\text { Slope }=k=\frac{\pi^{2} D_{\text {eff }}}{4 L^{2}}
$$

The Figure 5 shows two distinct drying stages, with two diffusion coefficients, that can be attributed to the change during freeze-drying process of the structure/porosity of the frozen coffee sample or to the change 
of the drying mechanism. It can be considered that during the sublimation, the sample structure becomes more porous, in the place of ice appear pores with larger diameters, which improve the mass transfer. So the value of $D_{\text {eff }}$ is higher in the second stage than in the first one, similar with other works $[12,14]$.

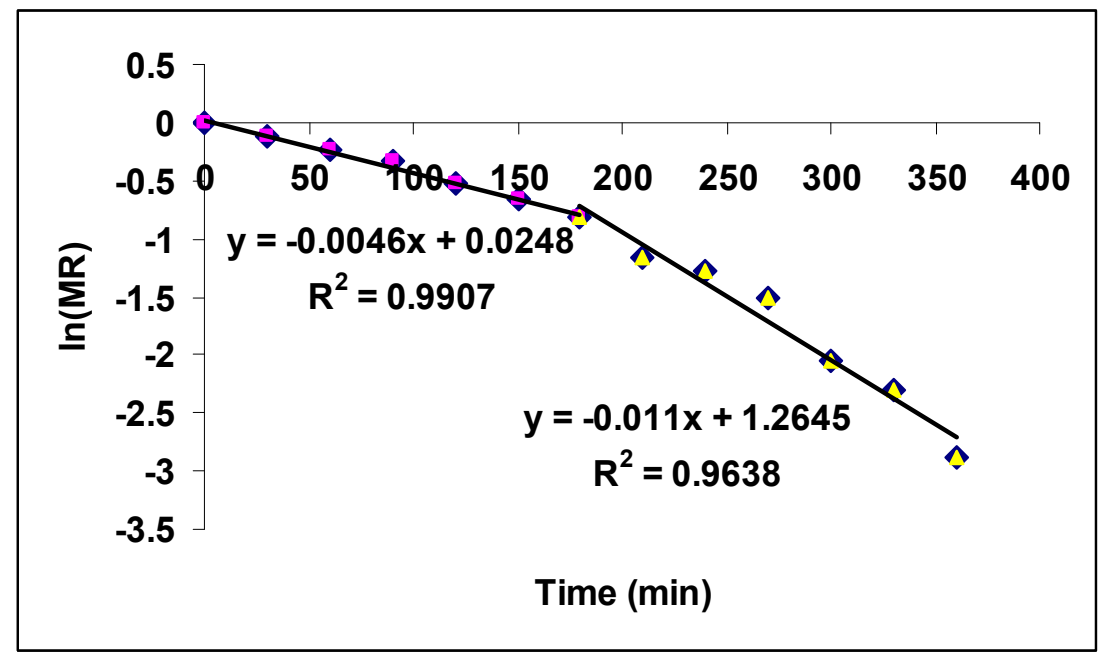

Figura 5. Determination of the diffusion coefficients

The experimental values of effective diffusion coefficient are found to vary from $2.286 \cdot 10^{-8} \mathrm{~m}^{2} / \mathrm{s}$ on the first stage to $5.467 \cdot 10^{-8} \mathrm{~m}^{2} / \mathrm{s}$ on the second stage (with an average value of $3.8765 \cdot 10^{-8} \mathrm{~m}^{2} / \mathrm{s}$ ).

\section{CONCLUSIONS}

The experimental data obtained for the coffee solution freezedrying were interpreted taken 10 mass transfer models used for thin-layer samples. The models were compared considering some statistical parameters. The Midilli model was found to show the best fit to experimental data. Comparative results are obtained by logarithmic, Wang and approximation of diffusion models.

The drying rates varying from $0.32 \mathrm{~kg} / \mathrm{kgm}^{2} \mathrm{~s}$ to $0.025 \mathrm{~kg} / \mathrm{kgm}^{2} \mathrm{~s}$, have shown the decrease of drying rate with the decrease of the moisture content, specific for the porous materials with low specific surface. 
The experimental values of effective diffusion coefficient, found to vary from $2.286 \cdot 10^{-8} \mathrm{~m}^{2} / \mathrm{s}$ on the first stage to $5.467 \cdot 10^{-8} \mathrm{~m}^{2} / \mathrm{s}$ on the second stage, was attributed to the change of the structure/porosity of the soluble coffee sample during the freeze-drying process.

\section{EXPERIMENTAL SECTION}

The coffee solution was prepared by boiling of $200 \mathrm{~g}$ pure grinded coffee from Firma Tchibo (procured from local market) in $500 \mathrm{~mL}$ hot water. The obtained suspension was filtered and than the concentrated solution was divided in equal samples and pleased in Petri dishes. The samples with the thickness of $7 \mathrm{~mm}$ of concentrated coffee placed in Petri dishes were first frozen for 30 minutes at $-80^{\circ} \mathrm{C}$ in the freezer and than the frozen samples were transferred inside the freeze dryer for a period of 6 hours under the pressure of $0.045 \mathrm{mbar}$ and a shelf temperature of $20{ }^{\circ} \mathrm{C}$. The condenser temperature was kept to $-50{ }^{\circ} \mathrm{C}$. Freeze-drying was carried out using a laboratory freeze dryer ALPHA 1-2 LD Plus, MARTIN CHRIST Gefriertrocknungsanlagen GmbH Germany.

The weight of each sample was measured at each 30 minutes in order to evaluate the water loss. The samples which were taking out from the freeze dryer were transferred first to the desiccators for attaining equilibrium. Two replications were done in order to verify the reproducibility of the experiment.

\section{REFERENCES}

1. C. Ratti, Journal of Food Engineering, 2001, 49, 311.

2. A. Ciurzynska, A. Lenart, Polish Journal of Food and Nutrition Sciences, 2011, 61(3), 165.

3. J. P. George, A. K. Datta, Journal of Food Engineering, 2002, 52, 89.

4. Y. Liu, Y. Zhao, X. Feng, Applied Thermal Engineering, 2008, 28, 675.

5. A. I. Liapis, M.J. Pikal, R. Bruttini, Drying Technology, 1996, 14(6), 1265-1300.

6. F. Jafar, M. Farid, Drying Technology, 2003, 21(2), 249.

7. S. Khalloufi, J. L., Robert, C. Ratti. Journal of Food Processing Engineering, 2005, 28(2), 107.

8. W. Wang, Mo. Chen and Guohua Chen, Chinese Journal of Chemical Engineering, 2012, 20(3), 551.

9. A. I. Liapis, R. J. Litcheld, Chemical Engineering Science, 1979, 34, 975.

10. H. Sadikoglu, A. I. Liapis, Drying Technology, 1997, 15(3/4), 791. 
11. M. Karel, "Freeze Drying and Advanced Food Technology", S. A. Goldblith, L. Rey, W. W. Rothmayr, Eds. Academic Press: NY, 1975, 177.

12. A. Muthukumaran, "Foam-mat Freeze Drying of Egg White and Mathematical Modeling", PhD Thesis, 2007.

13. V. Kirmaci, T. Menlik, H. Usta, Journal of Engineering and Technological Sciences, 2013, 1, 22.

14. A. Miclăuş (Ghirişan), Studia UBB Chemia, 2015, 60(1), 147.

15. B. K. Bala, "Drying and Storage of Cereal Grains", Enfield N.H: Science Pub. 1997, chapter 3.

16. K. Sacilik, A. K. Elicin, Journal of Food Engineering, 2006, 73, 281.

17. C. Ratti, "Handbook of food powders: processes and properties", Woodhead Publishing Series in Food Science, Technology and Nutrition, Edited by: B. Bhandari, N. Bansal, M. Zhang and P. Schuck, 2013, 57. 
